\title{
REKONSTRUKSI POLITIK HUKUM PEMBERANTASAN KORUPSI MELALUI STRATEGI PENGUATAN PENYIDIK DAN PENUNTUT UMUM INDEPENDEN KPK
}

\author{
(Reconstruction Of Corruption Eradication Legal Policy Through Strengthening of \\ Corruption Eradication Commission's Independent Investigator And Prosecutor)
}

\author{
Ria Casmi Arrsa \\ Peneliti Pusat Pengembangan Otonomi Daerah (PPOTODA) \\ Universitas Brawijaya \\ JI.M.T. Haryono Nomor 169 Malang 65145 Jawa Timur \\ Email:ppotoda@gmail.com
}

Naskah diterima: 3 Oktober 2014; revisi: 24 Nopember 2014; disetujui: 28 Nopember 2014

\begin{abstract}
Abstrak
Indeks Persepi Korupsi (IPK) Indonesia pada tahun 2013 menggambarkan posisi Indonesia berada pada skala eskalasi poin yang belum bergeser secara signifikan. Kondisi tersebut mengharuskan adanya komitmen dari Pemerintah dan segenap komponen masyarakat untuk secara berkelanjutan melakukan upaya-upaya yang masif dan sistematis dalam menjalankan agenda pemberantasan korupsi di Indonesia. Dengan menggunakan metode yuridis normatif tulisan ini akan membedah apa yang menjadi dasar urgensi rekonstruksi politik hukum pemberantasan korupsi, serta bagaimanakah model rekonstruksi politik hukum dalam pemberantasan korupsi tersebut. Hasil penelitian menunjukkan bahwa salah satu upaya masif dan sistematis dimaksud dapat dilakukan melalui gagasan rekonstruksi politik hukum pemberantasan korupsi melalui strategi penguatan penyidik dan penuntut umum independen Komisi Pemberantasan Korupsi. Gagasan ini dimaksudkan sebagai sarana untuk mendorong arah politik kebijakan dan regulasi agar menopang kinerja KPK secara optimal dalam bidang pencegahan dan/atau penindakan korupsi dalam skala pusat sampai daerah. Rekonstruksi politik hukum diarahkan pada argumentasi baik dalam ranah substansi hukum, struktur hukum, kultur hukum, dan saranaprasarana melalui penguatan sumber daya manusia baik dari sisi kualitas, kuantitas maupun anggaran. Oleh karenanya dukungan sektor politik diperlukan agar strategi pemberantasan korupsi inheren dengan gagasan yang termaktub di dalam Konvensi Perserikatan Bangsa-Bangsa Menentang Korupsi (United Nations Convention Against Corruption, UNCAC) Kata kunci: Rekonstruksi, Politik Hukum, Korupsi, Penegakan Hukum
\end{abstract}

\begin{abstract}
Indonesia's corruption perception index (CPI) in 2013 illustrates Indonesia position in escalation stage point has not improved significantly. These conditions requires commitments from the Government and all society components to make massive and systematic efforts continuously in carrying out eradication of corruption agenda in Indonesia. Using juridis normative method this article will discuss urgents points of reconstruction of corruption eradication legal policy, also how the model of reconstruction of corruption eradication legal policy its self. This research results shows that one massive and systematic efforts can be done through reconstruction idea of ecorruption eradication legal political strategy through strengthening independent investigator and prosecutor of the Corruption Eradication Commission. This idea intends to encourage political direction of policy and regulation in order to support optimal performance of the Commission in the field of prevention and/or execution of corruption both in central and region scale. Political legal reconstruction directs to the substance of the argument in legal substance, legal structure, legal culture, and infrastructure through the empowerment of human resources from quality, quantity and budget aspects. Therefore political sector strategy supports needed in order to eradicate corruption inherent with the idea that inline within United Nations Convention against Corruption, UNCAC (United Nations Convention Against Corruption).
\end{abstract}

Keywords: Reconstruction, Legal policy, Corruption, Law Enforcement 


\section{A. Latar Belakang}

Perkembangan pemberantasan korupsi di Indonesia berjalan secara pasang surut di tengah dominasi kekuatan kepentingan politik dan kekuasaan. ${ }^{1}$ Dalam kondisi tersebut perilaku korupsi di Indonesia telah menjalar di beberapa sendi kehidupan negara yang berjalan secara sistemik dan terorganisir mulai pada tingkat pemerintahan pusat sampai pada pemerintahan di daerah. Menurut Laporan BPK ${ }^{2}$ berdasarkan laporan semester I Tahun 2011 memaparkan sebuah temuan bahwa BPK menemukan 11.430 kasus senilai Rp26,68 triliun. Sebanyak 3.463 kasus senilai Rp7,71 triliun merupakan temuan ketidak patuhan yang mengakibatkan kerugian, potensi kerugian, dan kekurangan penerimaan negara.

Mengacu pada hasil audit diatas temuan terhadap ketidak hematan, ketidakefisienan, dan ketidakefektifan sebanyak 7.967 kasus senilai Rp18,96 triliun. Lebih lanjut Ketua BPK juga melaporkan, berdasarkan hasil pemeriksaan Tahun 2005 sampai dengan Semester I Tahun 2011, BPK memberikan 191.751 rekomendasi senilai Rp103,19 triliun. Rekomendasi ini harus ditindaklanjuti oleh entitas yang diperiksa antara lain dengan melakukan perbaikan Sistem Pengendalian Intern (SPI), tindakan administratif, dan/atau penyetoran kas atau penyerahan aset ke negara/daerah/perusahaan. Sejalan dengan data tersebut nampaknya potensi kerugian negara akibat penyimpangan dalam pengelolaan keuangan negara telah menjalar di berbagai instansi lembaga negara yang menjalankan sistem kenegaraan baik pada tingkat eksekutif, legislatif, dan yudikatif. ${ }^{3}$ Problem zona negara gagal ${ }^{4}$ yang akan dihadapi oleh bangsa Indonesia tentunya bukanlah suatu anasir atau analisis yang dangkal mengingat bahwa menurut laporan yang dilakukan oleh Study World Economic Forum dan Universitas Harvard pada tahun 2002 tentang negara gagal, menunjukkan bahwa dari 59 negara Indonesia masuk karakteristik negara gagal karena tingginya angka kriminalitas dan kekerasan, korupsi merajalela, serta suasana ketidak pastian yang tinggi. Potret buram pemberantasan korupsi di Indonesia nampak pada semakin mewabahnya perilaku korupsi di berbagai lini penyelenggaraan negara. Adapun fakta terkait hal itu dapat disajikan dalam data sebagaimana berikut ini.

Tabel 1: Perbandingan Skor dan Urutan Terkorup Institusi di Indonesia Menurut Barometer Korupsi Global dari Tahun ke Tahun

\begin{tabular}{llllll}
\hline \multirow{2}{*}{ Institusi } & \multicolumn{5}{c}{ Barometer Korupsi Global } \\
& \multicolumn{4}{c}{$\begin{array}{c}\text { dari tahun ke tahun** (rentang skor 1-5; } \\
\text { 1=tidak korup sama sekali, 5=sangat korup) }\end{array}$} \\
\hline & 2004 & 2005 & 2006 & 2007 & 2009 \\
\hline Partai Politik & $4,4^{*}$ & $4,2^{*}$ & 4,1 & 4,0 & 4,0 \\
\hline Legislatif & $4,4^{*}$ & 4,0 & $4,2^{*}$ & 4,1 & $4,4^{*}$ \\
\hline Kepolisian & 4,2 & 4,0 & $4,2^{*}$ & $4,2^{*}$ & - \\
\hline
\end{tabular}


\begin{tabular}{llllll}
\hline Lembaga Peradilan & 4,2 & 3,8 & $4,2^{*}$ & 4,1 & 4,1
\end{tabular}

*=institusi dengan skor paling tinggi/paling korup pada tahun itu **= Survei BKG dilaksanakan pertama kali tahun 2003, tetapi metodenya berbeda dengan survei-survei di tahun-tahun selanjutnya.

Sumber: Transparansi International 2009

Lebih lanjut mengacu pada data diatas potret buram wabah korupsi juga telah menjalar di berbagai daerah. Kasus korupsi yang terjadi di berbagai daerah yang melibatkan sejumlah petinggi pemerintahan, dalam catatan Indonesian Corruption Watch (ICW) berkembang sangat pesat. Daftar tersebut akan semakin bertambah panjang, mengingat masih banyak sejumlah pelaku kejahatan korupsi yang melibatkan petinggi pemerintahan daerah yang belum mendapatkan izin pemeriksaan dari institusi diatasnya. Berikut sejumlah kasus korupsi yang melibatkan sejumlah kepala pemerintahan di daerah :

Tabel 2: Kasus Korupsi yang Melibatkan Sejumlah Kepala Pemerintahan di Daerah

(Provinsi, Kabupaten, Kota)

\begin{tabular}{|c|c|c|c|c|c|}
\hline \multirow[t]{6}{*}{ Kasus Koorupsi Gubernur } & No & Nama & Jabatan & Kasus & Besar Kerugian \\
\hline & 1 & AJ Sondakh & Gubernur Sulut & Manado Beach Hotel & Rp. 11,5 Miliar \\
\hline & 2 & Zaenal bahar & Gubernur Sumbar & Kasus Korupsi Dana APBD 2002 & Rp. 5,9 Miliar \\
\hline & 3 & Djoko Munandar & Gubernur Banten & Dana Perumahan Dewan & Rp. 10 Miliar \\
\hline & 4 & Lalu Serinata & Gubernur NTB & $\begin{array}{l}\text { Kasus Korupsi APBD NTB tahun } 2001 \text { dan } \\
\text { tahun } 2004\end{array}$ & Rp. 24 Miliar \\
\hline & 5 & Abdullah Puteh & Gubernur NAD & Mark up Pengadaan Helikopter MI-2 & Rp. 6,8 Miliar \\
\hline \multirow[t]{4}{*}{ Korupsi Walikota } & 1 & Badrul Kamal & Walikota Depok & Korupsi Dana Rutin Kota Depok & Rp. 9,4 Miliar \\
\hline & 2 & Zuiyen Rais & Walikota Padang & Kasus Korupsi APBD & \\
\hline & 3 & Khalik Effendi & Walikota Bengkulu & $\begin{array}{l}\text { Kasus Korupsi Pembangunan Gedung } \\
\text { Seleksi Tilawatil Quran Nasional (STQN) }\end{array}$ & Rp. 65 Miliar \\
\hline & 4 & Raymundus Sailan & Walikota Singkawang & APBD 2003 & Rp. 1,95 Miliar \\
\hline \multirow[t]{15}{*}{ Korupsi Bupati } & 1 & Gahral Syah & Bupati Halmahera Barat & $\begin{array}{l}\text { Kasus korupsi dana pemekaran wilayah } \\
\text { pada 2002-2003 }\end{array}$ & Rp. 23,5 Miliar \\
\hline & 2 & Drs. Chairullah & Bupati Serdang, Sumut & $\begin{array}{l}\text { Kasus dugaan korupsi penggunaan dana } \\
\text { bantuan proyek Pembinaan Keamanan } \\
\text { Ketertiban dan proyek Bantuan } \\
\text { Kemasyarakatan Tahun } 2004\end{array}$ & Rp. 2,3 Miliar \\
\hline & 3 & Lukman Abu Nawas & Bupati Kendari & $\begin{array}{l}\text { Penyelewangan keuangan Negara } \\
\text { dengan cara mengeluarkan dana APBD } \\
2003 \text { untuk pesangon DPRD }\end{array}$ & Rp. 2 Miliar \\
\hline & 4 & Syamsul Hadi & Bupati Banyuwangi & Korupsi Pembelian Kapal Sri Tanjung & Rp. 15 Miliar \\
\hline & 5 & H.M. Madel & Bupati Sarolangun, Jambi & Korupsi Pembangunan Dermaga Ponton & Rp. 3,5 Miliar \\
\hline & 6 & Ibrahim Agustinus & Bupati Kupang & $\begin{array}{l}\text { Dana Proyek Pengadaan } 300 \text { Unit } \\
\text { Rumpon }\end{array}$ & Rp. 3,9 Miliar \\
\hline & 7 & Bahruddin H. Lisa & Bupati Barito Selatan & Kayu Ilegal & Rp. 80 Miliar \\
\hline & 8 & Bina B Bahajak & Bupati Nias & Dana PSDA Kehutaann tahun 2001 & Rp. 2 Miliar \\
\hline & 9 & Anthony Bagul D & Bupati Ruteng, Flores & Pembangunan Rumah Pribadi Bupati & Rp. 3 Miliar \\
\hline & 10 & Masdjumi & Bupati Berau & $\begin{array}{l}\text { Kasus korupsi peniadaan pungutan Dana } \\
\text { Reboisasi (DR) dan Propinsi Sumber Daya } \\
\text { Hutan (PSDH) }\end{array}$ & Rp. 88 Miliar \\
\hline & 11 & Imam Muhadi & Bupati Blitar & Kasus korupsi uang kas Kab. Blitar & Rp. 32 Miliar \\
\hline & 12 & Imam Yuliansyah & Bupati Barito Utara, Kalteng & Lelang illegal logging & Rp 3 Miliar \\
\hline & 13 & Felix Fernandez & Bupati Flores Timur, NTT & $\begin{array}{l}\text { Pembelian tanah untuk lokasi terminal } \\
\text { Waibalun, Larantuka dan kasus } \\
\text { pembelian kapal ikan }\end{array}$ & Belum diketahui \\
\hline & 14 & Daniel Banunaek & Bupati Timor Tengah Selatan & $\begin{array}{l}\text { Kasus dana purna bakti Timor Tengah } \\
\text { Selatan, 1999-2004 }\end{array}$ & Rp 1 Miliar \\
\hline & 15 & $\begin{array}{l}\text { Christian Nehemian } \\
\text { Dellak }\end{array}$ & Bupati Rote Ndao, NTT & $\begin{array}{l}\text { Proyek pengadaan dua unit kapal } \\
\text { penampung ikan dan biaya operasional } \\
10 \text { unit kapal penangkap ikan tahun } \\
\text { anggaran } 2002\end{array}$ & \\
\hline
\end{tabular}

Sumber: Korupsi Gubernur, Walikota dan Bupati, ICW. 
Berdasarkan data diatas menujukkan bahwa secara kuantitatif jumlah kejahatan korupsi di Indonesia tergolong sangat tinggi. Praktek korupsi didaerah sedemikian meruyak karena disebabkan minimnya integritas pejabat daerah akibat tidak dilaksanakannya prinsip-prinsip good governance maupun terjadinya conflict of interest dalam relasi ketertundukan Pemerintah pada rezim penguasa modal yang memberikan sumbangsih pendanaan dalam kontestasi pilkada. Beranjak dari uraian dimaksud sangat penting untuk memotret laju perkembangan korupsi di Indonesia. Berikut ini penulis paparkan perkembangan Indeks Persepsi Korupsi (IPK) Indonesia.

Grafik 1: Indeks Persepsi Korupsi (IPK) Indonesia Tahun 2013

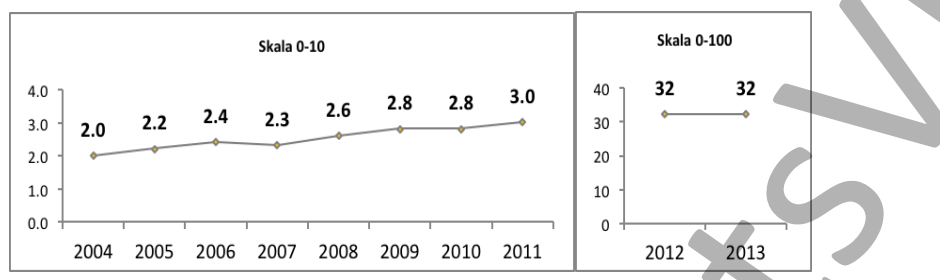

Sumber: UNODC Tahun 2014

Gambar di atas menunjukkan secara time series skor Indeks Persepsi Korupsi (IPK) Indonesia selama sembilan tahun terakhir. Khusus di dua tahun terakhir, nampak bahwa IPK Indonesia tidak bergerak dari angka 32. Ini menunjukkan, bahwa kerja-kerja serius untuk melawan korupsi tidaklah boleh berhenti pada satu titik, dimana pencapaian terbaik diperoleh. Perang melawan korupsi harus dilakukan oleh segenap komponen bangsa. Berdasarkan per- kembangan indeks persepsi korupsi dimaksud maka praktek korupsi dan lemahnya penegakan hukum merupakan ancaman bagi stabilitas negara. Di dalam United Nation Convention Againts Corruption-2003 menyatakan bahwa ancaman yang ditimbulkan oleh korupsi terhadap stabilitas dan keamanan masyarakat yaitu dapat merusak lembaga-lembaga negara dan tata nilai demokrasi, nilai etika, prinsip keadilan serta mengacaukan pembangunan yang berkelanjutan dan penegakan hukum. Hal senada juga diungkapkan oleh UNODC bahwa5:

"Corruption is a complex social, political and economic phenomenon that affects all countries. Corruption undermines democratic institutions, slows economic development and contributes to governmental instability. corruption attacks the foundation of democratic institutions by distorting electoral processes, perverting the rule of law and creating bureaucratic quagmires whose only reason for existing is the soliciting of bribes. Economic development is stunted because foreign direct investment is discouraged and small businesses within the country often find it impossible to overcome the "start-up costs" required because of corruption".

Dalam upaya pemberantasannnya di butuhkan upaya ekstra keras dari aparatur penegak hukum khususnya bagi Komisi Pemberantasan Korupsi (KPK) RI sebagai lembaga independen yang profesional dan tanpa tebang pilih dalam memberantas tindak pidana korupsi. Sebagai institusi penegak hukum tentunya KPK RI juga di lengkapi Sumber Daya Manusia sebagai penunjang tugas dalam pemberantasan tindak pidana korupsi. Namun demikian di tengah derasnya pengaduan dan 
laporan terkait dengan kejahatan korupsi oleh masyarakat menyebabkan KPK nampak masih lemah dari sisi kuantitas, integritas, dan independensi dari aspek tenaga penyelidik, penyidik, maupun penuntut umum.

Menurut Busryo Muqoddas mengutarakan bahwa total Sumber Daya Manusia di KPK saat ini terdapat 99 penyidik aktif dan 47 jaksa penuntut. Namun demikian di tengah mewabahnya kasus korupsi nampak terobosan dalam penegakan hukum yang progresif diutarakan oleh Ketua KPK RI Abraham Samad yang menghendaki adanya tenaga penyidik independen sebagai sistem pendukung pemberantasan korupsi dari tingkat pusat sampai daerah mengingat bahwa pengadilan Tindak Pidana Korupsi telah di bentuk di daerah.

Strategi untuk mewujudkan kebijakan hukum sebagaimana di maksud tentunya harus dimaknai sebagai bentuk progresifitas KPK dalam penegakan hukum mengingat menurut Undang-Undang Nomor 30 Tahun 2002 tentang Komisi Pemberantasan Tindak Pidana Korupsi Membuka peluang untuk merekrut tenaga penyidik independen. Analisis awal terkait dengan peluang tersebut antar lain termaktub di dalam ketentuan Pasal 25 yang berbunyi "Komisi Pemberantasan Korupsi: menetapkan kebijakan dan tata kerja organisasi mengenai pelaksanaan tugas dan wewenang Komisi Pemberantasan Korupsi". Selanjutnya ketentuan Pasal 28 yang berbunyi, "Komisi Pemberantasan Korupsi dapat melakukan kerja sama dengan pihak lain dalam rangka pengembangan dan pembinaan organisasi Komisi Pemberantasan Korupsi".

Berdasarkan uraian diatas menunjukkan bahwa KPK RI memiliki peran penting dalam rangka mewujudkan penegakan hukum progresif dalam pemberantasan tindak pidana korupsi demi terwujudnya keadilan bagi seluruh rakyat Indonesia. Penguatan sisi kuantitas dan kualitas personel KPK diharapkan mampu mendorong arah penegakan lebih proaktif dan responsif untuk mengontrol jalannya pemerintahan dari pusat sampai ke daerah baik dari sisi substansi hukum, aparatur penegak hukum, budaya hukum, maupun sarana dan prasarana penunjang dalam penegakan hukum. Dari latar belakang diatas maka dalam penulisan karya ilmiah ini di rumuskan permasalahan apakah yang menjadi dasar urgensi rekonstruksi politik hukum pemberantasan korupsi melalui strategi penguatan penyidik dan penuntut umum independen KPK RI? serta bagaimanakah model rekonstruksi politik hukum dalam pemberantasan korupsi melalui strategi penguatan penyidik dan penuntut umum independen KPK RI yang handal?

\section{Metodologi Penulisan}

Penulisan karya ilmiah ini menggunakan metode Yuridis Normatif yaitu mengkaji dan menganalisis efektifitas penegakan hukum dalam pemberantasan korupsi melalui strategi penguatan personal KPK RI baik dari sisi substansi peraturan perundang-undangan di bidang pemberantasan tindak pidana korupsi, Kelembagaan, kultur, dan sarana-prasarana yang tersedia. Pendekatan penulisan yang digunakan dalam karya ilmiah ini yaitu Pertama, pendekatan perundang-undangan (statuta approach), ${ }^{6}$ yaitu pendekatan yang digunakan dalam penulisan hukum yang dilakukan dengan menelaah undang-undang yang bersangkut

Peter Mahmud Marzuki, Penelitian Hukum, (Jakarta: Kencana, 2005) hlm 93. 
paut dengan isu hukum di bidang penegakan hukum dalam pemberantasan tindak pidana korupsi. Kedua, adalah metode perbandingan (comparative approach) yaitu membandingkan struktur dan peran lembaga pemberantasan korupsi di beberapa negara. Ketiga, adalah metode pendekatan konsep (conseptual approach) ${ }^{7}$ yaitu menawarkan konsep strategis penguatan personel independen KPK yang berintegritas terhadap pemberantasan tindak pidana korupsi di Indonesia sebagai sarana mewujudkan keadilan sosial dalam sistem penegakan hukum di Indonesia.

\section{Pembahasan}

1. Dasar Urgensitas Rekonstruksi Politik Hukum Pemberantasan Korupsi Melalui Strategi Penguatan Penyidik dan Penuntut Umum Independen KPK RI.

Proses hukum adalah salah satu pilihan yang tepat dalam menyelesaikan kasus korupsi sebagi perwujudan konsep negara hukum yang dimandatkan oleh konstitusi. Perihal ini memperlihatkan munculnya beberapa indikasi yang membawa harapan terjadinya perbaikan upaya penegakan hukum seperti: Pertama, terlihat adanya kecenderungan instansi penegak hukum untuk lebih responsif dan adanya kesediaan aparat penegak hukum untuk membangun kerjasama yang lebih kuat dengan aktor pendorong. Kedua, meski tidak terjadi pada semua kasus, namun secara umum dimana terdapat sekelompok aktor pendorong yang kuat maka akan ditemui proses hukum yang cenderung berjalan dengan lebih transparan dan relatif lebih cepat. ${ }^{8}$

Berpangkal dari gambaran umum diatas maka keberadaan KPK RI sebagai lembaga pemberantasan tindak pidana korupsi baik dari sisipencegahan maupun penindakan merupakan kebutuhan penting dalam rangka mewujudkan Indonesia yang bersih dari kejahatan korupsi. Namun demikian di tengah tingginya tingkat korupsi di Indonesia belum diimbangi dengan ketersediaan tenaga penyidik dan penuntut umum. Hambatan inilah yang pada akhirnya menjadikan kinerja pemberantasan korupsi di Indonesia berjalan secara lambat. Hal ini tidak bisa di pungkiri mengingat bahwa ketersediaan tenaga penyidik dan penuntut umum di KPK RI jumlahnya terbatas.

Hambatan personalia KPK RI dari sisi kualitas maupun kuantitas juga mendapat sorotan tajam dari dunia akademik terkait dengan konstruksi hukum pengadaan personel independen KPK baik tenaga penyelidik, penyidik maupun penuntut umum. Menurut Hibnu Nugroho ${ }^{9}$ mengutarakan bahwa selama ini dalam sistem penyidikan tipikor di Indonesia, lembaga penyidik tindak pidana korupsi yang ada yaitu penyidik Kepolisian, penyidik Kejaksaan dan penyidik KPK memiliki sistem tersendiri yang diatur dalam undang-undang terpisah-pisah.

Lebih lanjut Nugroho menyatakan bahwa Korupsi akan terus terjadi selama pemberantasan terhadap korupsi masih bersifat sektoral dan egosentrisme korps masih 
tinggi antara Kepolisian, Kejaksaan dan KPK. Terkotak-kotaknya lembaga penyidikan tipikor menciptakan kecenderungan instansi sentris atau fragmentasi. Sehingga mempengaruhi jalannya proses penanganan perkara dari hasil penyidikan yang dilakukan penyidik kepolisian kepada Jaksa Penuntut Umum. Belum adanya keintegraliasasian dan keselarasan ide-ide, gagasan-gagasan, nilai-nilai, norma-norma dan peraturan yang menjadi landasan kode etik profesi, menyebabkan output yang ada tidak berbentuk suatu keselarasan hasil penyidikan tindak pidana korupsi.

Berdasarkan uraian diatas maka langkah kongkrit yang menjadi dasar urgensi rekonstruksi politik hukum pemberantasan tindak pidana korupsi harus diarahkan pada penguatan personel independen KPK baik dalam lingkup penyelidik, penyidik, maupun penuntut umum. Adapun langkah progresif penegakan hukum sebagaimana dimaksud harus berlandaskan pada indikator efektifitas hukum baik dari sisi substansi, struktur, kultur, sarana, dan prasarana. Berpangkal dari indikator efektifitas hukum sebagaimana dimaksud dapat di jabarkan oleh penulis melalui analisis sebagai berikut:

\section{a. Aspek Substansi Hukum}

Indikator substansi hukum sebagai model alternatif strategi penguatan personel independen KPK di letakkan pada konteks kerangka peraturan perundang-undangan yang mendukung peluang KPK untuk bisa memformulasi tenaga penyelidik, penyidik, dan penuntut umum yang bersifat independen. Adapun kerangka yuridis sebagaimana dimaksud antara laian terdiri dari:

Tabel 3. Analisis Peraturan Perundang-Undangan Yang Mendukung Penguatan Personel Independen KPK RI

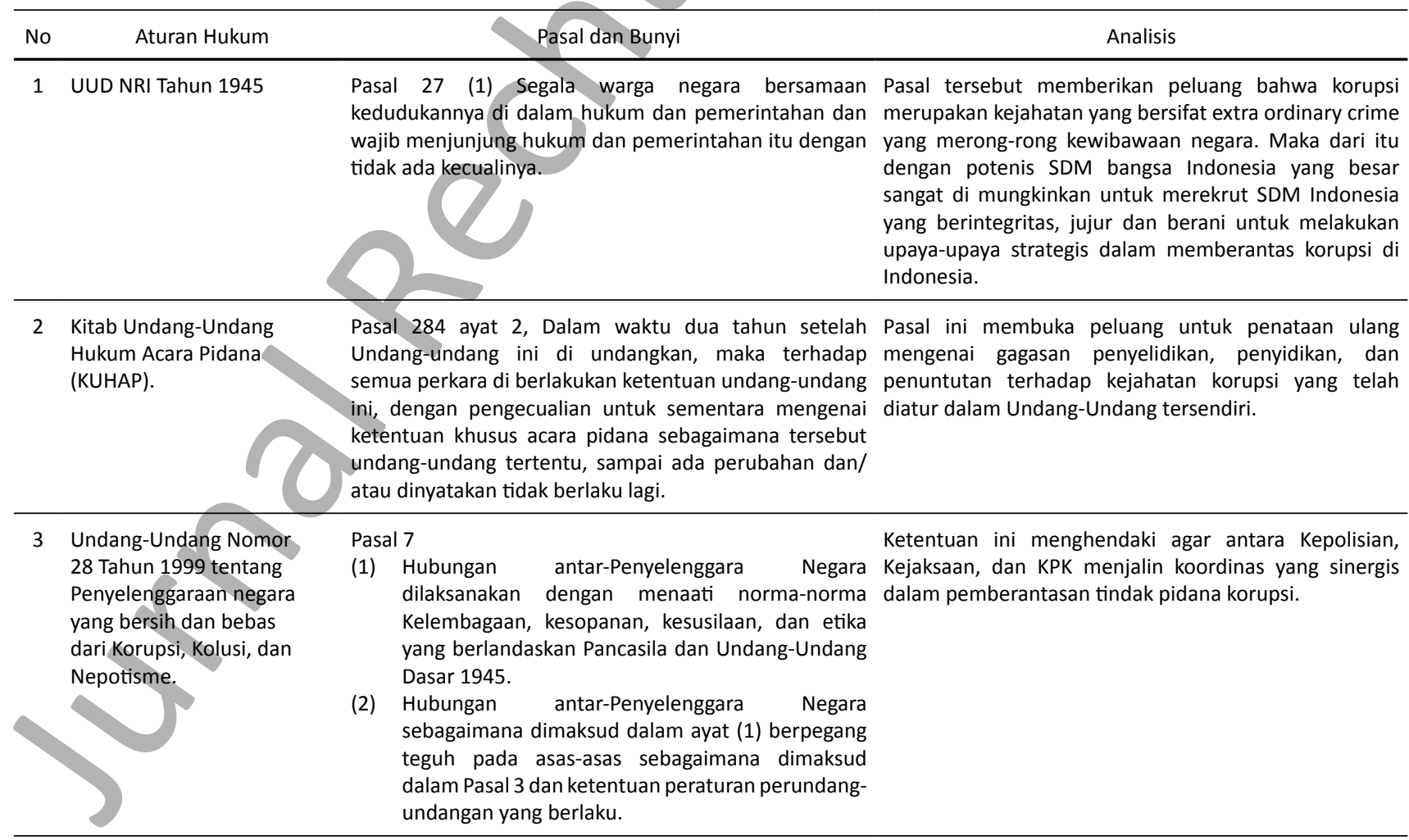




\begin{tabular}{|c|c|c|c|}
\hline No & Aturan Hukum & Pasal dan Bunyi & Analisis \\
\hline 4 & $\begin{array}{l}\text { Undang-Undang Nomor } \\
31 \text { Tahun } 1999 \text { tentang } \\
\text { Pemberantasan Tindak } \\
\text { Pidana Korupsi Jo Undang- } \\
\text { Undang Nomor } 20 \text { Tahun } \\
2001 \text { tentang Perubahan } \\
\text { Atas Undang-Undang } \\
\text { Nomor } 31 \text { Tahun } 1999 \\
\text { tentang Pemberantasan } \\
\text { Tindak Pidana Korupsi. }\end{array}$ & $\begin{array}{l}\text { Pasal } 26 \\
\text { Penyidikan, penuntutan, dan pemeriksaan di sidang } \\
\text { pengadilan terhadap tindak pidana korupsi, dilakukan } \\
\text { berdasarkan hukum acara pidana yang berlaku, kecuali } \\
\text { ditentukan lain dalam Undang-undang ini. }\end{array}$ & $\begin{array}{l}\text { Ketentuan ini memberikan peluang untuk memperkuat } \\
\text { posisi KPK dalam hal penyidikan dan penututan } \\
\text { terhadap tindak pidana korupsi melaui revitalisasi } \\
\text { fungsi penyelidikan, penyidikan, dan penuntutat melalui } \\
\text { upaya sinkronisasi, harmonisasi, dan sinergitas antara } \\
\text { Kepolisian dan Kejaksaan. }\end{array}$ \\
\hline 5 & $\begin{array}{l}\text { Undang-Undang Nomor } 30 \\
\text { Tahun } 2002 \text { tentang Komisi } \\
\text { Pemberantasan Tindak } \\
\text { Pidana Korupsi. }\end{array}$ & $\begin{array}{l}\text { Pasal } 3 \\
\text { Komisi Pemberantasan Korupsi adalah lembaga negara } \\
\text { yang dalam melaksanakan tugas dan wewenangnya } \\
\text { bersifat independen dan bebas dari pengaruh kekuasaan } \\
\text { manapun. } \\
\text { Pasal } 4 \\
\text { Komisi Pemberantasan Korupsi dibentuk dengan tujuan } \\
\text { meningkatkan daya guna dan hasil guna terhadap upaya } \\
\text { pemberantasan tindak pidana korupsi. } \\
\end{array}$ & $\begin{array}{l}\text { Ketentuan ini memberikan peluang untuk } \\
\text { mengkonstruksi secara yuridis keberadaan personel KPK } \\
\text { yang independen mengingat bahwa Pelemahan KPK bisa } \\
\text { terjadi melalui undang-undang dan intervensi politik } \\
\text { dalam pemilihan komisioner KPK. Selain itu, KPK juga } \\
\text { rentan penyusupan oleh kelompok kepentingan yang } \\
\text { terganggu, baik kepentingan bisnis, politik, maupun } \\
\text { penegak hukum lain. Bentuk-bentuk } \\
\text { Infiltrasi ke tubuh KPK, sangat mungkin terjadi, } \\
\text { mengingat tenaga vital KPK di bidang penyidikan dan } \\
\text { penuntutan masih dipasok dari luar institusi itu. Penyidik } \\
\text { dari Polri dan penuntut umum dari Kejaksaan. Kalaupun } \\
\text { tidak terjadi pengkhianatan, minimal ada loyalitas ganda. } \\
\text { Apalagi mereka hanya bertugas sementara di KPK dan } \\
\text { akan kembali ke institusi awal. Terhadap kemungkinan } \\
\text { infiltrasi ini, harus disiapkan penyidik dan penuntut } \\
\text { independen. Semua lembaga pemberantasan korupsi } \\
\text { di negara lain juga menuju ke sana, yaitu independensi } \\
\text { penyidik ataupun penuntut umum. }\end{array}$ \\
\hline 6 & $\begin{array}{l}\text { Undang-Undang Nomor } \\
7 \text { Tahun } 2006 \text { tentang } \\
\text { Pengesahan UNCAC } 2003\end{array}$ & & $\begin{array}{l}\text { Melalui Undang-Undang No. 7/2006, Pemerintah } \\
\text { Indonesia meratifikasi United Nations Convention } \\
\text { Against Corruption, UNCAC (Konvensi Perserikatan } \\
\text { Bangsa-Bangsa Menentang Korupsi -2003). Otomatis, } \\
\text { Indonesia wajib mengimplementasikan ketentuan } \\
\text { UNCAC secara penuh. Tahun 2010, Pertemuan yang me- } \\
\text { review Implementasi ketentuan UNCAC bagi Indonesia } \\
\text { dilakukan oleh Inggris dan Uzbekistan. Hasilnya, } 32 \\
\text { rekomendasi ketentuan UNCAC diharapkan dapat } \\
\text { dilakukan di Indonesia. Dari } 32 \text { rekomendasi, terdapat } 25 \\
\text { rekomendasi terkait yang perlu dilakukan penyesuaian } \\
\text { regulasi yang telah diatur (existing regulation), yaitu } \\
\text { diantaranya; } \\
\text { a. } 9 \text { rekomendasi tentang kriminalisasi tindak pidana } \\
\quad \text { korupsi; } \\
\text { b. } 2 \text { rekomendasi mengenai sistem pemidanaan } \\
\quad \text { dalam KUHAP; } \\
\text { c. } 1 \text { rekomendasi mengenai perampasan aset; } \\
\text { d. } 2 \text { rekomendasi mengenai ekstradisi; } \\
\text { e. } 9 \text { rekomendasi mengenai bantuan timbal balik } \\
\text { f. masalah pidana; } 2 \text { rekomendasi terkait peraturan lainnya. } \\
\text { Saat ini, Indonesia sudah melaksanakan } 13 \text { dari } 25 \\
\text { rekomendasi di atas yang terakomodasi ke dalam } \\
\text { berbagai rancangan undang-undang. Beberapa yang } \\
\text { belum terakomodasi diantaranya masih terhambat } \\
\text { dikarenakan dikarenakan adanya perbedaan sistem } \\
\text { hukum nasional serta terkait erat dengan kedaulatan dan } \\
\text { kepentingan nasional. Keterhambatan ini patut untuk } \\
\text { dicari solusinya, dan salah satu cara yang bisa dilakukan } \\
\text { korupsi musuh bersama, melalui kerja bareng antar } \\
\text { elemen bangsa, Indonesia kemudian membuat sebuah } \\
\text { grand strategy melawan korupsi. }\end{array}$ \\
\hline
\end{tabular}




\begin{tabular}{|c|c|c|c|}
\hline No & Aturan Hukum & Pasal dan Bunyi & Analisis \\
\hline 7 & $\begin{array}{l}\text { Peraturan Presiden No. } 55 \\
\text { Tahun } 2012 \text { tentang Stranas } \\
\text { PPK Jangka Panjang Tahun } \\
\text { 2012-2025 dan Jangka } \\
\text { Menengah Tahun 2012- } \\
2014 .\end{array}$ & & $\begin{array}{l}\text { Stranas PPK diimplementasikan melalui berbagai } \\
\text { Aksi Pencegahan dan Pemberantasan Korupsi (Aksi } \\
\text { PPK). Hingga saat ini, telah dilaksanakan tiga tahapan } \\
\text { Aksi PPK yang dilaksanakan yakni (1) Aksi PPK } 2011 \\
\text { berdasarkan Inpres No. } 9 \text { Tahun 2011; (2) Aksi PPK } \\
2012 \text { berdasarkan Inpres No. } 17 \text { Tahun 2011, serta; (3) } \\
\text { Aksi PPK } 2013 \text { berdasarkan Inpres No. } 1 \text { Tahun } 2013 \\
\text { dan Inpres Nomor } 2 \text { Tahun 2014. Sebagai gambaran, } \\
\text { di tahun } 2013 \text { tercatat } 111 \text { Pemerintah Daerah dan } 32 \\
\text { (tigapuluh dua) Kementerian/Lembaga terlibat dalam } \\
\text { pelaksanaan aksi PPK berdasarkan Inpres } 1 \text { Tahun } 2013 . \\
\text { Dan di tahun 2014, seluruh entitas pemerintah daerah } \\
\text { (Propinsi/Kabupaten/Kota) beserta } 84 \text { (delapan puluh } \\
\text { empat) Kementerian/Lembaga/Institusi bersama-sama } \\
\text { melaksanakan Aksi PPK yang terurai pada Inpres No. } \\
2 \text { Tahun } 2014 \text { tentang Aksi PPK. Hal yang juga tidak } \\
\text { kalah pentingnya dalam Stranas PPK adalah pelibatan } \\
\text { masyarakat untuk ikut bersama melakukan upaya } \\
\text { pencegahan dan pemberantasan korupsi yang dilakukan } \\
\text { oleh Pemerintah. Upaya melibatkan masyarakat, tentu } \\
\text { harus sejalan dengan kemampuan dari masing-masing } \\
\text { kelompok masyarakat dalam mengapresiasi dan } \\
\text { mendukung kinerja Pemerintah melaksanakan Stranas } \\
\text { PPK. Apresiasi dan dukungan positif yang diberikan } \\
\text { masyarakat, pada akhirnya menuntut upaya diseminasi } \\
\text { secara luas atas substansi isi dari rekomendasi UNCAC } \\
\text { dan STRANAS PPK. Dengan memberikan pemahaman } \\
\text { yang benar diharapkan dapat memperbesar gelombang } \\
\text { masiv masyarakat untuk mengatakan TIDAK dan } \\
\text { MELAWAN segala bentuk KORUPSI di Indonesia. }\end{array}$ \\
\hline
\end{tabular}

Sumber: Analisis Bahan Hukum Penulis

\section{b. Aspek Struktur Kelembagaan KPK}

Salah satu indikator lemahnya penegakan hukum ditandai dengan lemahnya sanksi yang dijatuhkan terhadap pelaku tindak pidana korupsi yang melibatkan aktor pemerintah, individu, maupun korporasi. Kondisi penegakan hukum seakan-akan tajam kebawah dan tumpul keatas. Hal ini senada dengan apa yang diutarakan oleh Donald Black bahwa semakin dekat hukum dengan kekuasaan maka daya kontrolnya akan cenderung melemah.

Pada dasarnya, praktek korupsi, kolusi, dan nepotisme (KKN) berlangsung dengan adanya kerjasama antara dua pihak, yaitu pihak yang mengambil atau menerima dengan pihak yang memberikan. Mungkin dalam hal korupsi, bisa saja terjadi tanpa ada pihak yang secara aktif menjadi pemberi, misalnya dalam hal seseorang yang melakukan korupsi dengan mengambil dana negara atau masyarakat yang ada di bawah kewenangan atau pengelolaannya.

Boleh saja dikatakan bahwa dosa terbesar ada pada pihak yang menerima karena dialah yang merugikan negara/masyarakat, namun pihak yang memberi juga salah karena berkolusi atau bekerjasama, sebagai 'accomplice' dalam tindak pidana tersebut. ${ }^{10}$ Berdasarkan uraian

$10 \quad$ Fithriadi Muslim dan Edi Nasution, Menjerat Koruptor Dengan Undang-Undang Tindak Pidana Pencucian Uang, Makalah ini disampaikan pada Seminar Nasional dan Dialog Interaktif dengan tema "Apa dan Mengapa Tindak Pidana Korupsi dan Pencucian Uang Merajalela" yang diselenggarakan oleh Lembaga Pengabdian Kepada Masyarakat (LPKM) Universitas Negeri Padang bekerjasama dengan Pro Justitia Institute Jakarta dan Harian Umum Singgalang di Hotel Pangeran Beach, Padang pada tanggal 19 November $2011 \mathrm{hlm} 1$. 
dimaksud maka efektifitas hukum dalam konteks penegakan hukum pemberantasan korupsi terletak pada aspek struktur dalam hal ini adalah aparatur penegak hukum. Secara institusional struktur organisasi KPK RI adalah sebagai berikut ini.

\section{1) Lembaga Pemberantasan Korupsi di Hongkong}

Keresahan masyarakat Hongkong terhadap perilaku korupsi tiba pada puncaknya ketika seorang Kepala Polisi dari warga negara asing Peter Godber menggelapkan uang sejumlah HK\$ 4,3 juta. Demonstrasi pun pecah untuk

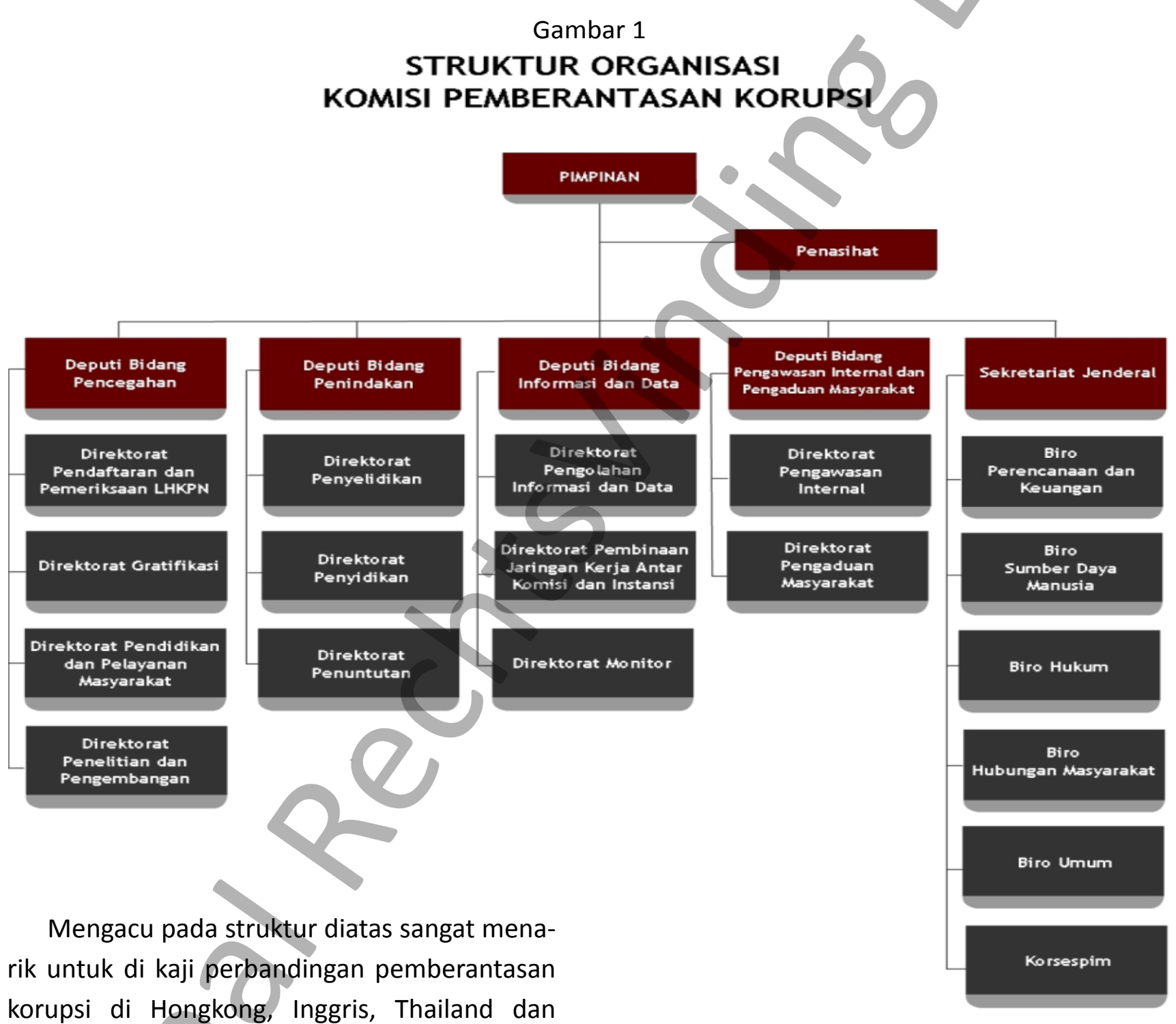

Singapura. Adapun perbandingan kelembagaan sebagaimana dimaksud adalah: ${ }^{11}$

11 Lembaga Adminsitrasi Negara (LAN), Strategi Penanganan Korupsi Di Negara-Negara Asia Pasifik, (Jakarta: Lembaga Administrasi Negara Pusat Kajian Administrasi Internasional, 2007) hlm 57-93. 
menuntut pemerintah melakukan langkahlangkah kongkrit dalam menuntaskan kasus ini dan memberantas korupsi di tubuh Kepolisian. Sampai pada tahun 1981, ICAC telah melakukan hampir 500 kajian tentang berbagai kebijakan dan praktik yang berlaku di instansi-instansi pemerintah. Selain itu lebih dari 10.000 pegawai pemerintah yang telah menghadiri pelatihan yang dilakukan ICAC. Di samping itu, untuk meningkatkan etos kerja dan disiplin personil ICAC dibangun suatu kode etik yang mengikat seluruh jajaran ICAC dalam melaksanakan tugas dan kewenangannya sehari-hari.

Kode etik yang dikembangkan dalam ICAC adalah : (a) menganut prinsip integritas dan fair play, (b) menghormati hak-hak yang diakui secara hukum bagi semua orang, (c) menjalankan tugas tanpa rasa takut, praduga atau itikad tidak baik, (d) bertindak sesuai dengan aturan hukum yang berlaku, (e) tidak mengambil keuntungan dari kewenangan atau jabatan yang diemban, (f) menjaga rahasia, (g) menerima tanggung jawab atas tindakan yang dilakukan dan instruksi, (h) menjaga kesopanan dan mengendalikan ucapan maupun tindakan, (i) berusaha meraih keunggulan pribadi dan profesional.

Dalam studi yang dilakukan oleh Direktorat Litbang KPK pada tahun 2006 disebutkan bahwa ICAC Hongkong adalah model yang universal dan ideal bagi sebuah lembaga anti korupsi. ICAC dikatakan ideal karena mempunyai landasan hukum yang kuat, didukung oleh anggaran yang memadai, memiliki tenaga ahli yang mencukupi dan yang utama adalah dukungan dan komitmen pemerintah yang tinggi dan konsisten.

\section{2) Lembaga Pemberantasan Korupsi di Inggris $^{12}$}

Inggris memilik lembaga anti korupsi yang bernama Serious Fraud Office (SFO) yang berdiri pada tahun 1988. Dengan luas wilayah 130.395 $\mathrm{km}^{2}$ dan jumlah penduduk 53.013.000 jiwa memberikan gambaran terkait desain kebijakan pemberantasan korupsi yang dijalankan oleh SFO dengan kewenangan yang dimilik antara lain penyelidikan, penyidikan dan penuntutan.

\section{3) Lembaga Pemberantasan Korupsi di Thailand}

Thailand memiliki lembaga anti korupsi yang bernama National Anti Corruption Commission (NACC) yang berdiri pada Tahun 1957. Dengan luas wilayah $514.000 \mathrm{~km}^{2}$ dan 64.700 .000 jiwa Kebijakan Pemerintah Thailand telah membentuk kantor perwakilan NACC dengan jumlah pegawai 1.300. Desain pemberantasan korupsi yang dijalankan oleh NACC memiliki kewenangan dalam hal pencegahan, penyelidikan, dan penyidikan.

\section{4) Lembaga Pemberantasan Korupsi di Singapura}

Di Singapura sebelum tahun 1952, seluruh kasus-kasus korupsi diselidiki oleh unit kecil dalam Singapore Police Force yang disebut dengan Anti-Corruption Branch. Dalam perkembangannya unit tersebut tidak berjalan efektif, khususnya dalam menyelidiki petugaspetugas kepolisian yang korup. Kelemahan yang utama disebabkan karena terbatasnya kewenangan yang dimiliki unit tersebut dan diperparah dengan adanya konflik kepentingan

12 Komisi Pemberantasan Korupsi, Jalan Berliku Pemberantasan Korupsi, (Jakarta: KPK-RI, 2012) hlm 43. 
yang terjadi karena para penyidik terlihat segan untuk memeriksa rekan-rekan mereka yang juga dari kepolisian. Pada tahun 1952 Pemerintah Singapura dibawah PM Lee Kuan Yew membentuk lembaga yang disebut Corrupt Practices Investigation Bureau (CPIB) sebagai sebuah lembaga anti korupsi yang terpisah dari kepolisian untuk melakukan penyelidikan semua kasus-kasus korupsi.

Dalam sejarahnya CPIB merupakan salah satu lembaga anti korupsi tertua di dunia. Untuk mempercepat upaya pemberantasan korupsi Pemerintah Singapura pada tahun 1960 mengesahkan undang-undang anti korupsi yang baru yang disebut dengan Prevention of Corruption Act. Dalam undang-undang ini, wewenang dari CPIB diperluas dan hukuman atas tindak pidana korupsi ditingkatkan. Saat ini, sesuai dengan Bab 241 undang-undang tersebut, CPIB memiliki kewenangan yang memadai untuk memberantas korupsi. Secara fungsi, CPIB memilikifungsi untuk (a) menyelidiki kasus korupsi/berindikasi korupsi, (b) mencegah terjadinya korupsi; dan (c) kombinasi antara menyelidiki dan mencegah tindakan korupsi.

Berdasarkan perbandingan kelembagaan pemberantasan korupsi diatas maka potret buram kinerja aparat penegak hukum dalam hal ini adalah kepolisian dan kejaksaan sudah selayaknya menjadikan KPK RI memilik peran sentral dala pemberantasan korupsi yang secara bertahap melepaskan diri dari institusi Kepolisian dan kejaksaan sehingga menjadi lembaga independen yang berintegritas, profesional, dan akuntable.

\section{c. Aspek Budaya Hukum (Culture of law)}

Faktor budaya hukum dalam konteks penegakan hukum yang terbangun pada kondisi birokrasi, politik, maupun bisnis di Indonesia telah menempatkan pada posisi yang transaksional. Artinya setiap kejahatan yang korupsi yang dilakukan oleh elit kekuasaan politik, elit bisnis, maupun elit birokrasi selalu terjadi celah transaksional antara yang berkepentingan dengan aparatur penegak hukum mulai pada tingkat kepolisian, kejaksaan, dan peradilan merupakan mata rantai jalannya mafia hukum di Indonesia. Argumentasi penulis di perkuat dengan adanya laporan dari Masyarakat Transparansi Indonesia (MTI) ${ }^{13}$ yang menyebutkan bahwa 72 kepala daerah dan atau pejabat daerah yang mengadu ke Komisi III DPR terkait dugaan pemerasan yang kerap dilakukan oknum penyidik kejaksaan. Potret buram kultur hukum transaksional inilah yang senantiasa menjadi dasar argumentasi empiris bahwa KPK RI harus di perkuat secara kelembagaan maupun personel baik tenaga penyelidik, penyidik, dan penuntut umum agar kinerja kontrol terhadap birokrasi dan korporasi dalam meminimalisasi upaya tindak pidana korupsi bisa berjalan secara cepat tanpa adanya intervensi.

\section{d. Aspek Sarana dan Prasarana}

Kemajuan teknologi penyadapan menjadikan instrumen yang handal bagi penguatan personel independen KPK RI dalam menjalankan fungsi pengawasan terhadap jalannya tata pemerintahan yang bersih. Meskipun masih kontroversial keberadaan teknologi penyadapan 
telah berhasil mengungkap sejumlah kasus korupsi besar yang melibatkan pejabat negara, elit politik maupun pelaku bisnis. Kedepan dalam rangka mewujudkan progresifitas dalam penegakan hukum di bidang pemberantasan korupsi kehadiran payung hukum yang kuat terkait dengan teknologi penyadapan sangat dibutuhkan guna merespon kebutuhan masyarakat terkait dengan upaya untuk meminimalisasi praktek-praktek transaksional dalam pengelolaan keuangan negara maupun proyek-proyek pengadaan barang yang dijalankan oleh lembaga-lembaga negara.

\section{Model Rekonstruksi Politik Hukuk Pemberantasan Korupsi Melalui Strategi Penguatan Penyidik dan Penutut Umum Independen KPK RI}

Berdasarkan dasar urgensitas diatas maka di butuhkan adanya model penguatan penyidik dan penutut umum independen KPK RI yang handal. Sebagai langkah kongkrit maka desain penguatan sebagaimana dimaksud dapat di jabarkan berikut ini:
Berdasarkan gambar diatas maka efektifitas penegakan hukum dalam rangka memberikan penguatan kinerja KPK di bidang pemberantasan korupsi dapat di tempuh melalui strategi peningkatan kualitas dan kuantitas terhadap tenaga penyidik dan penuntut umum independen KPK RI. Peningkatan kuantitas dan kualitas tenaga penyidik dan penuntut umum sangat terbuka mengingat bahwa berdasarkan indikator efektifitas hukum yang di uraikan pada pembahasan pertama memberikan argumentasi yuridis mengenai konstruksi hukum peningkatan kualitas dan kuantitas penyidik maupun penuntut umum KPK RI. Adapun bentuk kongkrit sebagaimana dimaksud dapat dijelaskan antara lain:

\section{a. Penguatan KPK dari sisi Kualitas}

Pencegahan terhadap tindak pidana korupsi kiranya memiliki peran penting dalam mewujudkan kesadaran terhadap bahaya laten korupsi bagi pembangunan suatu negara. Maka dari itu metode pencegahan yang sangat

Gambar 2. Rekonstruksi Politik Hukum Penguatan Penyidik dan Penutut Umum Independen KPK RI yang Handal

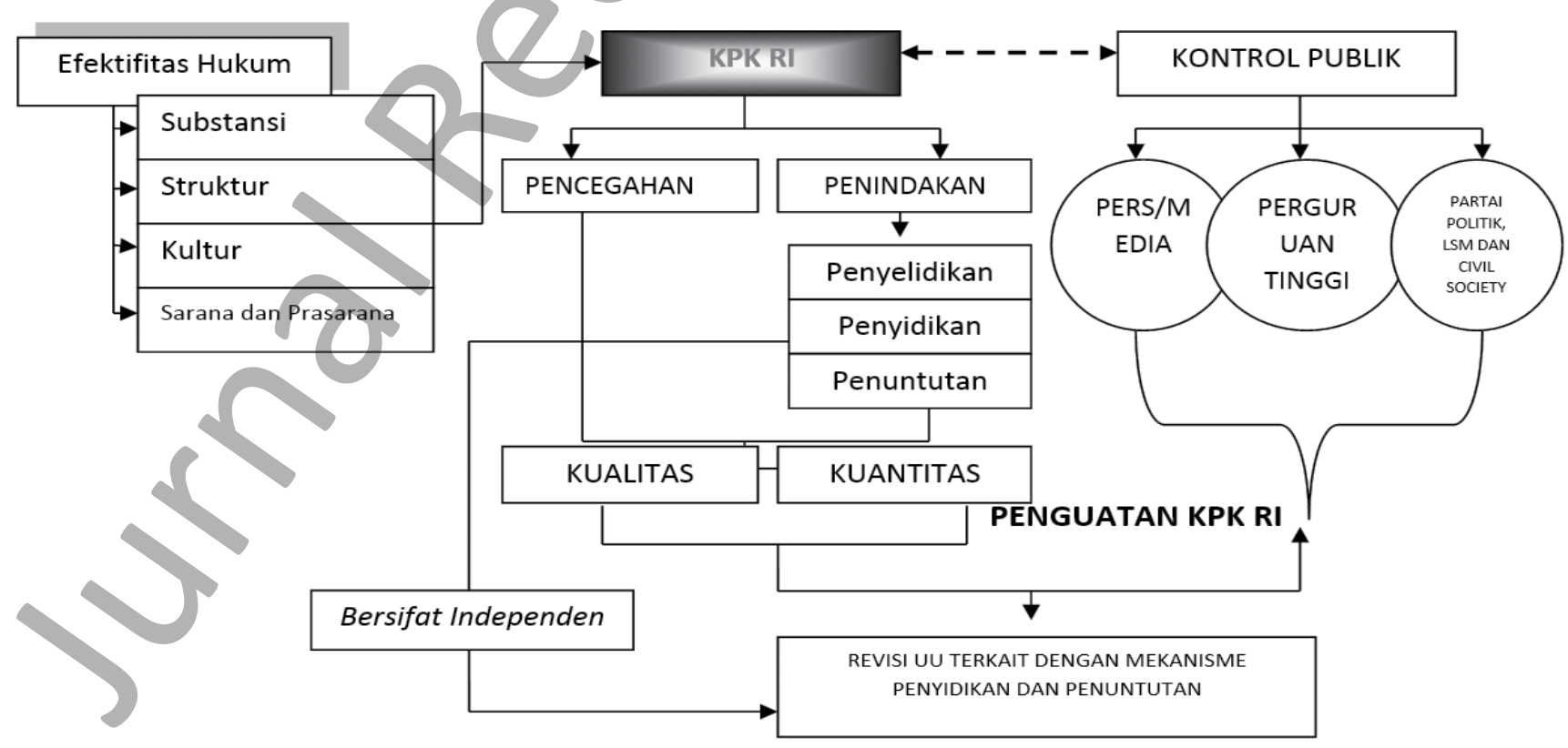


efektif adalah dengan melibatkan Perguruan Tinggi, LSM, Pers, Partai Politik, dan Masyarakat melalui berbagai pendekatan baik secara kultural maupun secara berkelanjutan melalui Pendidikan Anti Korupsi, Pendidikan Integritas, Pendidikan Karakter, Seminar, Sosialisasi, Kantin Kejujuran. Stretegi ini cukup memberikan efek dalam pemberantasan korupsi sebagaimana di praktekkan oleh The Community Relations Department (salah satu departemen dalam ICAC) telah berhasil merekrut 110 tenaga lokal, dan menerima lebih dari 10.000 laporan praktik korupsi, dan menangani lebih ari 19.000 events, seperti seminar, camps, eksibisi, dan kompetisi.

\section{b. Penguatan KPK dari sisi Kuantitas}

Strategi penguatan KPK dari sisi kuantitas yaitu penambahan tenaga penyelidik, penyidik, dan penuntut umum yang bersifat independen terpisah dari institusi Kepolisian dan Kejaksaan sangat dimungkinkan mengingat bahwa latar belakang dan perbandingan kelahiran lembaga pemberantasan korupsi di berbagai negara di dominasi oleh kekecewaan masyarakat terhadap kinerja aparatur Kepolisian dalam upaya pemberantasan kejahatan korupsi. Di Indonesia setiap tahun terdapat ribuan pengaduan dan kasus korupsi krusial yang terjadi. Sedangkan jumlah penyidik KPK tidak sampai 100 personel. Oleh karena itu, jumlah penyidik KPK terlampau kecil untuk menangani kompleksitas kasus korupsi di Indonesia.

Dari sisi anggaran untuk kinerja KPK yang tergolong besar pun, tidak menjamin menyelesaikan persoalan yang dihadapi KPK apabila jumlah personel KPK tidak ditambah. Sebagai dasar argumentasi yuridis dan komparatif adanya penambahan personel KPK RI adalah gambaran progresifitas penegakan hukum dalam pemberantasan korupsi pada lembaga pemberantasan korupsi yang ada di Hongkong. Lembaga pemberantasan korupsi di Hongkong memiliki penyidik sekitar 2.000 orang, padahal Hongkong lebih kecil dari Indonesia. Sehingga rasio penambahan personel KPK RI harus ditambah hingga 2.000 orang. Rasio jumlah 2000 sangat strategis mengingat bahwa di Indonesia telah di bentuk pengadilan tindak pidana korupsi di daerah. Maka dari itu dengan penambahan personel sebagaimana di maksud akan semakin mempercepat progresifitas penegakan hukum dalam pemberantasan korupsi. Demikian halnya di Malaysia bahwa kegagalan Unit Jenayah Khas (Unit Tindak Pidana Khusus) Kepolisian Diraja Malaysia yang gagal dalam memangani korupsi maka di bentuklah Badan Pencegah Rasuah (BPR) yang dilengkapi dengan tenaga penyidik profesional sehingga menjadikan pemberantasan korupsi berjalan secara efektif di masyarakat. ${ }^{14}$

\section{c. Penguatan KPK dari sisi Yuridis}

Berdasarkan dua strategi diatas maka strategi selanjutnya adalah perlu adanya dukungan dari masyarakat, LSM, perguruan tinggi, Partai politik untuk berkomitmen melakukan upaya revisi Undang-Undang Nomor 30 Tahun 2002 tentang Komisi Pemberantasan Tindak Pidana Korupsi untuk melakukan mekanisme sinkronisasi, harmonisasi dan pembagian kewenangan 
penyelidikan, penyidikan, dan penuntutan antara institusi kepolisian dan kejaksaan. Sebagaimana termaktub di dalam Pasal 11 Undang-Undang Nomor 30 Tahun 2002 menegaskan bahwa dalam melaksanakan tugas sebagaimana dimaksud dalam Pasal 6 huruf c, Komisi Pemberantasan Korupsi berwenang melakukan penyelidikan, penyidikan, dan penuntutan tindak pidana korupsi yang: melibatkan aparat penegak hukum, penyelenggara negara, dan orang lain yang ada kaitannya dengan tindak pidana korupsi yang dilakukan oleh aparat penegak hukum atau penyelenggara negara, mendapat perhatian yang meresahkan masyarakat; dan/ atau menyangkut kerugian negara paling sedikit Rp. 1.000.000.000,00 (satu milyar rupiah).

Mengacu pada dasar argumentasi yuridis di atas maka sudah selayaknya fokus penegakan hukum dalam pemberantasan korupsi menjadi domain KPK untuk menyelesaikannya. Berdasarkan pada tiga model penguatan KPK sebagaimana telah di uraikan diharapkan kedepan institusi KPK merupakan pilar penegakan hukum yang progresif dalam rangka mewujudkan sistem hukum nasional yang dapat menopang terlaksananya tata kelola pemerintahan yang baik (good governance) dalam penyelenggaraan negara di Indonesia.

\section{Penutup}

Berdasarkan pembahasan sebagaimana telah diuraikan diatas maka dapat diambil kesimpulan bahwa dasar urgensi rekonstruksi politik hukum pemberantasan korupsi di Indonesia di dasarkan pada indikator efektifitas hukum yang terdiri dari aspek substansi hukum dalam hal ini adalah peraturan perundangundangan yang membuka peluang untuk menerapkan tenaga penyidik dan penuntut umum independen KPK, struktur aparatur penegak hukum dalam hal ini adalah kelemahan institusi kepolisian dan kejaksaan dalam upaya pemberantasan korupsi, kultur hukum yaitu potret buram praktek mafia hukum di Indonesia, serta keberadaan sarana dan prasarana penunjang dalam mendukung pemberantasan korupsi yang efektif di Indonesia. Konstruksi hukum terhadap model penguatan tenaga penyidik dan penutut umum independen KPK RI bertumpu pada tiga aspek antara lain penguatan KPK secara kualitas, penguatan KPK secara kuantitas, dan penguatan KPK secara yuridis.

Berdasarkan kesimpulan diatas maka dalam artikel ini di rekomendasikan beberapa solusi antara lain: pertama, pemerintah dan DPR segera merevisi Undang-Undang Nomor 30 Tahun 2002 tentang Komisi Pemberantasanan Tindak Pidana Korupsi dan Undang-Undang yang mengatur tentang penyidikan dan penuntutan korupsi dengan tujuan untuk memperkuat dan menambah tenaga penyidik dan penuntut umum independen KPK RI guna mewujudkan progresifitas KPK dalam memberantas korupsi di Indonesia. Kedua, seyogyanya fungsi penyidikan dan penuntutan KPK bersifat independen terpisah dari institusi Kepolisian dan Kejaksaan guna memperkuat komitmen independensi, integritas, profesional, dan akuntable. Ketiga, dibutuhkan sinergitas dan partisipasi aktif antara peran media pers, LSM, Masyarakat, Perguruan Tinggi, dan partai politik untuk senatiasa bersinergi dengan KPK RI dalam rangka merumuskan model pencegahan dan penindakan yang efektif melalui road map pemberantasan korupsi yang progresif bagi terwujudnya penegakan hukum yang handal di masa yang akan datang. 


\section{DAFTAR PUSTAKA}

\section{Buku}

Badan Pemeriksa Keuangan, IHPS I Tahun 2011, (Jakarta: Badan Pemeriksa Keuangan, 2011).

Ibrahim, Johny, Teori dan Metode Penelitian Hukum Normatif, (Malang: Bayumedia 2006).

Isro, Negara Yang Gagal Ditinjau Dari Aspek Bernegara Yang Demokratis Berkeadilan, (Malang: Pidato Pengukuhan Guru Besar Hukum Tata Negara Pada FH Universitas Brawijaya Malang, 2011).

KASUM, 2010, Korupsi adalah Kejahatan HAM, Makalah disampaikan pada acara Munir Memorial Lecture (MML) IV Samanta Krida Convention Hall Universitas Brawijaya, 29 September 2010.

Komisi Pemberantasan Korupsi, Jalan Berliku Pemberantasan Korupsi, (Jakarta: KPK-RI, 2012).

Kompas, 2009, Kunci Keberhasilan KPK Hanya Kemauan Politik Pemerintah, diakses dari http://infokorupsi.com/id/korupsi. php?ac=3403\&l=kunci-keberhasilan-kpk-hanyakemauan-politik-dari-pemerintah, diakses pada tanggal 10 Maret 2012.

Lembaga Adminsitrasi Negara (LAN), Strategi Penanganan Korupsi Di Negara-Negara Asia Pasifik, (Jakarta: Lembaga Administrasi Negara Pusat Kajian Administrasi Internasional, 2007).

Marzuki, Peter Mahmud, Penelitian Hukum, (Jakarta: Penerbit Kencana, 2005).

Masyarakat Transparansi Indonesia, 2011, Ini 72 Kepala Daerah yang Melapor ke Komisi III karena Jadi 'Mesin ATM', diakses dari http:// www.transparansi.or.id, diakses pada tanggal 10 Maret 2012.

Muslim Fithriadi dan Edi Nasution, Menjerat Koruptor Dengan Undang-Undang Tindak Pidana Pencucian Uang, Makalah ini disampaikan pada Seminar Nasional dan Dialog Interaktif dengan tema "Apa dan Mengapa Tindak Pidana Korupsi dan Pencucian Uang Merajalela" yang diselenggarakan oleh Lembaga Pengabdian Kepada Masyarakat (LPKM) Universitas Negeri Padang bekerjasama dengan Pro Justitia
Institute Jakarta dan Harian Umum Singgalang di Hotel Pangeran Beach, Padang pada tanggal 19 November 2011.

Nugroho, Hibnu, Membangun Model Alternatif Untuk Integralisasi Penyidik Tindak Pidana Korupsi di Indonesia, (Semarang: Disertasi Program Doktor Ilmu Hukum Universitas Diponegoro Semarang, 2011).

Ratya, Mega Putra, 2014, Anggota Banggar Minta PPATK Rampungkan 2.000 Transaksi Mencurigakan, diakses dari http://www.detik. com, diakses pada tanggal 10 Februari 2014.

Rinaldi, Taufik, dkk, Memerangi Korupsi Di Indonesia Yang Terdesentralisasi Studi Kasus Penanganan Korupsi Pemerintahan Daerah, (Jakarta: Justice for The Poor Project World Bank 2007).

United Nation Office on Drugs and Crime (UNODC), 2014, Indeks Persepsi Korupsi (IPK) Indonesia Tahun 2013, Jakarta: UNODC Indonesia Office 2013.

\section{Peraturan}

Undang-Undang Dasar Negara Republik Indonesia Tahun 1945.

Kitab Undang-Undang Hukum Acara Pidana (KUHAP).

Undang-Undang Nomor 28 Tahun 1999 tentang Penyelenggaraan Negara yang Bersih dan Bebas Dari Korupsi, Kolusi, Dan Nepotisme.

Undang-Undang Nomor 31 Tahun 1999 tentang Pemberantasan Tindak Pidana Korupsi Jo Undang-Undang Nomor 20 Tahun 2001 tentang Perubahan Atas Undang-Undang Nomor 31 Tahun 1999 tentang Pemberantasan Tindak Pidana Korupsi.

Undang-Undang Nomor 30 Tahun 2002 tentang Komisi Pemberantasan Tindak Pidana Korupsi.

Undang-Undang Nomor 7 Tahun 2006 tentang Pengesahan United Nations Convention Against Corruption, 2003 (Konvensi Perserikatan BangsaBangsa Anti Korupsi, 2003).

Peraturan Presiden Nomor 55 Tahun 2012 tentang Stranas PPK Jangka Panjang Tahun 2012-2025 dan Jangka Menengah Tahun 2012-2014. 